\title{
The Many Faces of the Average Consumer: Is It Really So Difficult to Assess Whether Two Stripes Are Similar to Three?
}

\section{Lotte Anemaet}

\begin{abstract}
This article shows the necessity of including policy concerns, in particular the need to keep signs available for competitors, when assessing a likelihood of confusion. In the Adidas/Marca case, the CJEU ruled that the need to keep signs freely available for other economic operators cannot be a relevant factor in the infringement analysis. This is particularly problematic in relation to appealing signs such as stripe motifs. These signs not only serve as a source identifier, but also appeal to consumers and therefore give trademark owners an advantage over competitors on the market. In order to offer sufficient room for the concerns of trademark owners and competitors (and ultimately also consumers), it is essential to apply normative corrections not only in favour of trademark owners but also in favour of competitors. The current analysis of confusion in EU trademark law already contains a normative correction in favour of trademark owners. From an empirical perspective, the more distinctive the trademark, the less likely consumers are to be confused when confronted with a similar sign. The CJEU, however, assumes that consumers are more likely to be confused when confronted with signs that are similar to a highly distinctive trademark. In a trademark system where this normative correction is possible in favour of trademark owners, similar steps should be taken to give sufficient weight to the interests of competitors. In this light, this article concludes that the Adidas/Marca decision should be overruled.
\end{abstract}

Keywords Likelihood of confusion - Consumer perception - Court of Justice of the European Union · Need to keep free

The author is grateful to Martin Senftleben for helpful comments and suggestions. Lotte Anemaet is a visiting scholar at the Max Planck Institute for Innovation and Competition in Munich, Germany.

L. Anemaet $(\bowtie)$

Ph.D. Candidate, Vrije Universiteit Amsterdam, Amsterdam, The Netherlands

e-mail: 1.anemaet@vu.nl 


\section{Introduction}

Do national courts - in line with CJEU jurisprudence - assess a likelihood of confusion only factually (empirical approach focusing on consumer perception), or do they leave room for assumptions on how consumers ought to behave in the marketplace (normative approach) ${ }^{1}$ The branded goods industry has the capacity to invest in expensive marketing campaigns to educate consumers to perceive a sign as a source identifier. This industry can also invest in expensive empirical studies to demonstrate a distinctive character and a likelihood of confusion.

One might therefore expect that over-reliance on empirical findings in the likelihood-of-confusion assessment serves the interests of trademark proprietors. Teaching consumers in advertising to recognise a specific sign as a trademark, they can shape consumer perception in accordance with their desired scope of trademark protection. With an empirical approach, the trademark system seems at risk of becoming a self-serving mechanism for the branded goods industry.

Despite this risk, the CJEU held in the Adidas/Marca case that the consumer's perception should be decisive for the outcome of the infringement analysis; the Court was reluctant to introduce normative corrections of empirical findings, lend weight to the need to keep signs free in the confusion analysis and attach importance to the argument that competitors may also need freedom to use similar signs to decorate their products. ${ }^{2}$

The rejection of the need to keep free as a normative impact factor in the infringement analysis could have serious consequences for competitors seeking to enter into meaningful competition with the trademark owner. After all, consumer protection is not the only goal of trademark law. The EU trademark system also seeks to ensure undistorted competition and market transparency, which means that in addition to protecting consumers against confusion it is also supposed to create fair competition and guarantee the proper functioning of markets.

\footnotetext{
${ }^{1}$ Dinwoodie and Gangjee (2016), p. 345. For example, the CJEU's assumption that consumers are not in the habit of perceiving colours and shapes as trademarks is in fact a normative correction of the factual circumstances. See, for example, CJEU, judgment of 12 February 2004, case C-218/01 (Henkel), para 49; CJEU, judgment of 7 October 2004, case C-136/02 P (Mag Instrument/BHIM), para 31; CJEU, judgment of 12 January 2006, case C-173/04 P (Deutsche SiSi-Werke/BHIM), para 31; CJEU, judgment of 6 May 2003, case C-104/01 (Libertel); CJEU, judgment of 24 June 2004, case C-49/02 (Heidelberger Bauchemie $\mathrm{GmbH}$ ), para 39.

${ }^{2}$ CJEU, judgment of 10 April 2008, case C-102/07 (Adidas/Marca). The EU General Court recently ruled that Adidas' figurative mark representing three parallel stripes was invalid. Adidas' evidence of use of white stripes on black clothing could not be used to prove that the three-stripe mark had acquired distinctiveness through use in trade because Adidas had registered a logo with black stripes on a white background. The reverse of the colour scheme, in the General Court's view, could not be seen as an insignificant variation as compared to the registered form. This decision could open a more critical approach concerning a too broad protection mechanism of design elements in general, such as stripe motifs. Nevertheless, it remains to be seen whether the CJEU will also follow the General Court's strict interpretation. Furthermore, it cannot be said that brand owners such as Adidas lost power with regard to infringement proceedings. Of all Adidas cases, the Adidas/Marca case still holds true. A more critical approach towards the scope of protection of the three-stripe motif is therefore also desirable with regard to the infringement assessment. See General Court, judgment of 19 June 2019, case T-307/17 (Adidas/ Shoe Branding), paras 77-78.
} 
In light of the general debate about the gradual expansion of trademark rights, ${ }^{3}$ the Adidas/Marca decision raises the question whether the likelihood-of-confusion assessment is still working properly. Is it appropriate to rely almost exclusively on empirical findings concerning the public's perception when assessing whether a likelihood of confusion exists? Or does the CJEU create dysfunctional incentives and encourage traders to invest in marketing and branding campaigns concerning design elements that should better be kept free for competitors?

This article shows that the Adidas/Marca decision is problematic. The CJEU's focus on consumer perception without normative corrections in the likelihood-ofconfusion assessment is questionable. What the CJEU is actually protecting as a result of this jurisprudence is trademark owners' investments; the Court is less concerned with protecting consumers against confusion. It is time to reconsider the concept of likelihood of confusion: in the assessment, the likelihood-of-confusion question should only constitute one factor alongside other factors, such as the need to keep signs freely available for competitors on the market.

This article therefore argues that if we believe trademark owners should not have a potentially unlimited monopoly on design elements, with far-reaching possibilities for protection, the CJEU should allow national courts to make normative corrections not only in favour of trademark owners but also in favour of competitors in the likelihood-of-confusion assessment.

I first give an overview of literature and case law, demonstrating that trademark law is not only about protecting trademark owners but also about ensuring undistorted, fair and meaningful competition. I argue that the current infringement analysis in the confusion context is imbalanced since the CJEU has ruled in the Adidas/Marca case that no normative corrections should be made in favour of third parties' interests. In Sect. 3, I give an overview of literature that points out that the CJEU does offer broader protection against confusion in the case of highly distinctive marks, which is a normative correction in favour of trademark owners. Section 4 discusses national case law concerning the three-stripe motif of Adidas to illustrate that decisions were more balanced before than after the Adidas/Marca case. Section 5 concludes.

\section{Balancing Between Preserving the Public Domain and Protecting Consumers Against Confusion}

The reason to grant trademark owners an exclusive right is the belief that this form of market regulation ensures market transparency. In a transparent market, consumers can easily individualise different products and express their preference by selecting a specific product or service on the basis of trademarks. Signs that deceive consumers reduce the efficiency of the market because consumers inevitably purchase the wrong product. From an economic perspective, trademarks

\footnotetext{
${ }^{3}$ See, for example, Gangjee (2013); Senftleben (2013); Ramsey (2003), p. 1096; Wilf (1999), p. 17; McKenna (2007), pp. 1841, 1899.
} 
reduce search costs. ${ }^{4}$ Therefore, the primary purpose of trademark law is to indicate the commercial origin of goods and services offered in the marketplace:

In that context, the essential function of a trade mark is to guarantee the identity of origin of the marked goods or services to the consumer or end user by enabling him, without any possibility of confusion, to distinguish the goods or services from others which have another origin. For the trade mark to be able to fulfil its essential role in the system of undistorted competition which the Treaty seeks to establish and maintain, it must offer a guarantee that all the goods or services bearing it have been manufactured or supplied under the control of a single undertaking which is responsible for their quality. ${ }^{5}$

In order to fulfil this essential origin function, trademarks are protected against the use of identical or similar signs that are likely to cause confusion. ${ }^{6}$

However, to achieve undistorted competition, trademark protection must be balanced against other core values, such as free expression enhancing consumer information and consumer choice, ${ }^{7}$ and free competition preventing unnecessary market entry barriers. The recognition of a need to keep signs freely available offers competitors equal access to communication tools that can be used to inform consumers about product characteristics and compete for market shares. ${ }^{8}$

The fundamental principle of the need to keep free is reflected in several provisions in the Trade Mark Directive ${ }^{9}$ and the EU Trademark Regulation, ${ }^{10}$ and

${ }^{4}$ Griffiths (2008), p. 246; Bone (2006), p. 555; Strasser (2000), pp. 379-382; Carter (1990), p. 762; Landes and Posner (2003), pp. 166-168; Dogan and Lemley (2004), p. 786; McKenna (2007), p. 1844; Kur and Senftleben (2017), pp. 6-7; Economides (1988), p. 526.

5 CJEU, judgment of 12 November 2002, case C-206/01, paras 42, 48, 51 (Arsenal/Reed), para 48.

6 At the international level, the concept of likelihood of confusion is regulated by Art. 16(1) TRIPS Agreement.

7 Choice implies that consumers have access to more variety in terms of style, price, and content. If people had no choices, their lives would be almost unbearable. Variety in products leads to an increase in autonomy, control, and liberation, and it improves people's lives. However, more choice is not always good for consumers. In some situations, consumers are more likely to purchase something if they have fewer choices. Too many choices may demotivate consumers and lead to an information overload. Consumers who maximise their options may suffer from choice overload. They set high standards for themselves and want to make the best choice. Because they cannot examine all options, they may have doubts about making the best choice. In the end, "maximisers" are less happy with their choices because they were not able to consider all alternative products. See Szmigin and Piacentini (2015), pp. 107-108; Schwartz (2004).

8 Max Planck Institute (2011), p. 51; Phillips (2005), p. 392; Kur and Senftleben (2017), pp. 22-23; Senftleben et al. (2015); Sakulin (2011); Ramsey and Schovsbo (2013), p. 671; Simon Fhima (2013), p. 293; Burrell and Gangjee (2010), p. 544; Nasser 2009, p. 188; McGeveran (2008); AG Poiares Maduro, Opinion of 22 September 2009, cases C-236/08-238/08 (Google France and Google/Louis Vuitton et al.), para 102: "whatever the protection afforded to innovation and investment, it is never absolute. It must always be balanced against other interests, in the same way as trade mark protection itself is balanced against them. I believe that the present cases call for such a balance as regards freedom of expression and freedom of commerce."

9 Council Directive 2015/2436 of the European Parliament and of the Council of 16 December 2015 to approximate the laws of the Member States relating to trade marks, 2015 O.J. L336/1.

${ }^{10}$ Regulation (EU) 2017/1001 of the European Parliament and of the Council of 14 June 2017 on the EU trade mark, 2017 O.J. L154/1. 
recognised by the CJEU in several cases. ${ }^{11}$ For example, signs that fall under the grounds for refusal are excluded from trademark protection. ${ }^{12}$ Furthermore, it must be shown that the use of the sign is made "in the course of trade" and "in relation to goods or services". These protection requirements ensure that trademark rights do not affect social and cultural forms of use. The likelihood-of-confusion provision is directly related to the preservation of fair and undistorted competition. ${ }^{13}$

The trademark limitations also aim at a balance between the trademark proprietor's interests and free movement of goods and services within the internal market, and the competitor's interests in using a sign for legitimate purposes in accordance with honest practices. For instance, third parties are allowed to use descriptive signs identical or similar to protected trademarks or their components, where the trademark proprietor's legitimate interests are not adversely affected. ${ }^{14}$

In principle, trademark law and free competition do not conflict with one another. On the one hand, trademarks provide information about the commercial source of goods or services and enable consumers to repeat satisfactory purchases. Trademark owners are stimulated to keep the quality of their goods or services high and to invest in their goods and services. Competitors can choose a different sign if they want to freely offer their goods and services on the market. ${ }^{15}$

However, in practice, competition can only be neutral if the appropriation of the sign as such does not grant trademark owners a competitive advantage from which third parties are excluded. This requirement is largely fulfilled with respect to (fantasy) word marks and other traditional forms of trademarks. These signs are often available in sufficient supply, such that third parties do not experience entrance barriers in competing with similar products and services. ${ }^{16}$

On the other hand, appealing signs, such as the three-stripe motif of Adidas, are not available in unlimited numbers. Exclusive trademark rights on stripe motifs may affect the availability of design elements on the market and generate obstacles to competition. Stripe motifs contribute to the style and appearance of a specific product (i.e. sports clothing) and therefore give trademark proprietors a competitive advantage from the sign as such. ${ }^{17}$

\footnotetext{
${ }^{11}$ CJEU, judgment of 4 May 1999, cases C-108/97, C-109/97 (Windsurfing Chiemsee), para 26; CJEU, judgment 14 September 2010, case C-48/09 P, paras 56-57 (Lego Juris/BHIM); CJEU, judgment of 22 June 2006, case C-25/05 P (August Stork/BHIM), para 29; CJEU, judgment of 15 May 2014, case C-97/ 12 P (Louis Vuitton/BHIM); CJEU, judgment of 12 February 2004, case C-218/01 (Henkel), para 49; CJEU, judgment of 8 April 2003, cases C-53/01-C-55/01 (Linde), para 49; CJEU, judgment of 6 May 2003, case C-104/01 (Libertel), para 55.

12 Article 4 TMD 2015 and Art. 7 EU Trademark Regulation.

13 Senftleben (2015). In addition, protecting trademarks with a reputation beyond a likelihood of confusion, namely against unfair advantage being taken of their distinctive character and reputation, is justified because, and insofar as, this contributes to the creation and preservation of a system of undistorted competition.

14 Senftleben (2015).

15 Max Planck Institute (2011), p. 52.

16 Max Planck Institute (2011), p. 52.

17 Max Planck Institute (2011), p. 52.
} 
Trademark rights on appealing signs could hinder innovation and encourage standardisation. ${ }^{18}$ Competitors might be afraid of risking a legal procedure and as a result avoid using stripes on sports and leisure clothes altogether. ${ }^{19}$ In addition, a monopoly on appealing signs may also limit trademark owners' creativity and lead to standardisation. Brand owners have been obliged to use the same signs to keep the recognition level among consumers high. This could consequently lead to fewer investments in long-term product quality or developing new products. ${ }^{20}$ As long as non-distinctive signs can acquire distinctiveness through use in trade, trademark owners will invest in appealing signs which give them a competitive advantage.

Despite the fact that the principle of undistorted competition requires an evaluation of trademark issues in the light of all interests at stake, the CJEU explicitly expressed that the need for a sign to be freely available for competitors is not a relevant factor in the likelihood-of-confusion assessment. In the CJEU's view, such public-interest considerations are related to certain grounds for refusal of registration $^{21}$ and the revocation of trademark rights, ${ }^{22}$ but not to the likelihood-ofconfusion assessment. Ultimately, the likelihood-of-confusion assessment must be based on the public's perception and, accordingly, on empirical findings concerning this perception. Hence, if consumers perceive signs as similar and are therefore confused, this should be decisive for the outcome of the case. This outcome should not be affected by the argument that competitors may need to use particular signs to decorate their products in order to enter into meaningful competition with the trademark owner. ${ }^{23}$

As pointed out above, however, trademark law is not only about protecting trademark owners but also about ensuring undistorted, fair and meaningful competition. Therefore, at all levels - including the infringement analysis trademark owners' interests must be weighed against competitors' interests and the general consuming public. In light of this, it is remarkable that in the Adidas/Marca case, the CJEU explicitly refused to consider the need to keep protected signs available when determining the scope of protection. The current infringement analysis in the confusion context is therefore imbalanced. Without the option of making normative corrections in the confusion assessment, other core values, such as safeguarding freedom of competition and (commercial) freedom of expression, might become jeopardised.

\footnotetext{
18 Calboli (2018).

19 See also Calboli (2018), p. 293. In the absence of other stripe motifs, consumers may believe that all stripe motifs belong to Adidas and are possibly confused when they are confronted with similar stripe motifs. The more national courts give space to empirical factors in the infringement analysis, the more trademark owners are willing to support confusion claims with consumer studies, which will confirm that consumers are indeed confused when confronted with a similar sign. See also Gibson (2007), pp. 907-908, 912, 916.

20 Calboli, p. 288.

21 CJEU, judgment of 4 May 1999, cases C-108/97, C-109/97 (Windsurfing Chiemsee), para 25; CJEU, judgment of 8 April 2003, cases C-53/01-C-55/01 (Linde), para 73; CJEU, judgment of 6 May 2003, case C-104/01 (Libertel), para 53.

22 See CJEU, judgment of 27 April 2006, case C-145/05 (Levi Strauss), para 19.

23 CJEU, judgment of 10 April 2008, case C-102/07 (Adidas/Marca), para 30.
} 


\section{Infringement Analysis in Confusion Cases: Imbalanced}

It is established CJEU practice to offer broader protection against confusion in the case of highly distinctive marks. For this purpose, the CJEU assumes that "the more distinctive the earlier mark, the greater the likelihood of confusion". 24 This, however, is a normative correction in favour of trademark owners. When we study empirical findings, it becomes obvious that the opposite is true: the more distinctive the mark, the easier for consumers to identify even small deviations from the protected sign. Despite the heavy criticism aimed against it in legal literature, the CJEU has never reconsidered its statement that a likelihood of confusion increases as marks become more distinctive. However, the volume of literature arguing that the CJEU's statement is wrong casts increasing doubt on the CJEU's assumptions concerning consumer perception.

For example, Annette Kur and Martin Senftleben pointed out that consumers are less likely to be confused when a third party uses a sign that is similar to a wellknown trademark. A trademark that is well known to consumers is more likely to be remembered, and it is therefore less likely that consumers will have an "imperfect recollection" 25 when confronted with a similar trademark. ${ }^{26}$

Jeremy Phillips also argued that the CJEU ruling is in contradiction to reality. From an empirical perspective, it cannot be true that consumers are more likely to be confused the more distinctive a trademark is. The odds that consumers will not see the difference between one of the big market players like Coca-Cola and a similar sign is very low. In fact, consumers are far more likely to be confused and purchase the wrong product when it comes to less distinctive signs, such as "Eudermin" and "Eucerin" for body care products. The likelihood of confusion therefore decreases in proportion to how well known the trademark is. ${ }^{27}$

According to Burrell and Gangjee, it is therefore necessary to rediscover the fundamental principles on which trademark protection rests. It must be judicially acknowledged that there are times when the trademark's strength will reduce the

\footnotetext{
${ }^{24}$ CJEU, judgment of 11 November 1997, case C-251/95 (Puma/Sabel), para 24; CJEU, judgment of 29 September 1998, case C-39/97 (Canon v. Metro-Goldwyn-Mayer; Canon/Cannon), para 18; CJEU, judgment of 22 June 1999; case C-342/97 (Lloyd Schuhfabrik Meyer \& Co. GmbH/Klijsen Handel BV), paras $20,28$.

${ }^{25}$ CJEU, judgment of 22 June 1999; case C-342/97 (Lloyd Schuhfabrik Meyer \& Co. GmbH/Klijsen Handel $B V$ ), para 26.

${ }^{26}$ Kur and Senftleben (2017), p. 326. See also Fhima and Denvir (2015), p. 330.

${ }^{27}$ Phillips (2003), p. 352. CJEU, judgment of 22 June 1999, case C-342/97 (Lloyd Schuhfabrik Meyer \& Co. GmbH/Klijsen Handel BV), Nederlandse Jurisprudentie 2000, 375, case comment by DWF Verkade, para 6. See also Griffiths (2008), pp. 260-261; Raßmann (1997), p. 589; Seibt (2002), p. 470; Boes and Deutsch (1996), p. 168; Vierheilig (1982), p. 509; Zimmerli (1975), p. 138; David and Frick (2017), p. 250. See also OLG Düsseldorf, MuW 1912/XII, 259, Palmona/Baumona. See also the opinion of Advocate General Ruiz-Jarabo Colomer expressed in Arsenal Football Club Plc v. Matthew Reed, case C-206/01 [2002] E.T.M.R. 975, fn. 22: "The stronger the distinctive character of a sign, the less will be the likelihood of confusion. Registration of the name COCO-COLO for refreshments, and subsequent commercialisation of the goods, does not give rise to any confusion with the drinks distributed by COCACOLA, given the distinctiveness, penetration and reputation of that trade mark." See also the opinion of Jacob LJ in Reed Executive v. Reed Business Information [2004] EWCA Civ. 159, [2004] RPC (40) 767, paras 78 and 83 .
} 
risk of consumer confusion. In Burrell and Gangjee's view, some cases still justify offering additional protection. They argue that the reputation of a mark like "Viagra" might make it more likely that consumers will assume "Herbagra" is a brand extension for a similar but not identical product.

Nevertheless, other types of cases exist where consumers are less likely to be confused. The authors point out that it would be more difficult for Nike to argue that the use of a brand like "Nice" for the retailing of sporting goods would be likely to cause confusion. According to Burrell and Gangjee, no reasonable consumer is going to believe that Nike has suddenly chosen to rebrand itself as "Nice". Consumers will also not think that Starbucks has rebranded itself as "Charbucks" or that Louis Vuitton sells cheap toys for dogs under the "Chewy Vuiton" trademark. ${ }^{28}$ Brand owners would therefore undoubtedly have less success if judges assess the likelihoodof-confusion test empirically than if they follow an approach based on rules of experience stating that known marks must have a broader scope of protection. ${ }^{29}$

Despite being more cautious, Tobias Cohen Jehoram, Constant van Nispen, and Tony Huydecoper nevertheless indicated that the CJEU ruling is perhaps incorrect when it comes to luxury and fashion articles. These products are usually bought by a "brand conscious" public and this public will also note minor differences from that mark. However, Cohen Jehoram, van Nispen and Huydecoper argued that the legal theory of granting more protection to highly distinctive marks does follow practice, because the public does sooner associate with known marks than with unknown marks.

Although associations with known marks could sooner be characterised as taking unfair advantage of (or being detrimental to) the brand than that these associations cause direct or indirect confusion, the authors argue nevertheless that the matter of whether the allegedly infringing sign evokes associations with a known mark still plays a role in determining the scope of protection in confusion cases. In the authors' opinion, this shows that "the assessment of the likelihood of confusion is a legal test, not a factual test".

They argued that the use of the sign "Anti-Monopoly" for a game should therefore not only be forbidden because the third party's sign might take unfair advantage or be detrimental to the "Monopoly" brand (registered for games), but also because there is a likelihood of confusion, even if the majority of the public recognises that "Anti-Monopoly" competes with "Monopoly". 30

Han, Nunes and Drèze indicated that some luxury products, particularly those at the high end of the product line, do not necessarily bear a clear and prominent brand. Less expensive, louder products are targeted to a different class of consumer than subtler, more expensive goods. With respect to this higher class of consumer, brand owners also develop subtle cues by which the consumer can identify the products even in the absence of an explicit logo or brand name. For example, a Porsche is a Porsche, with or without the emblem. ${ }^{31}$ The reputation of the trademark

\footnotetext{
28 Burrell and Gangjee (2010).

29 Kabel (2005), p. 23.

${ }^{30}$ Cohen Jehoram et al. (2010), p. 285.

31 Han et al. (2010), p. 27.
} 
and the category of products, such as luxury, serve to make reasonable consumers less likely to be confused.

Gert Jan van de Kamp also suggested that from an empirical perspective it could be argued that the CJEU ruling is probably incorrect. However, in his view, the perception of the public should be assessed normatively. Empirical findings should not be by definition decisive; rather, what is relevant is what consumers ought to perceive. $^{32}$

Stefan Risthaus argued that because of the many associations evoked in the consumers' brain, consumers might be confused when a third party's sign displays fewer major differences and the product is only seen briefly. On the other hand, he also argued that slight differences between signs are more likely to be noticed because consumers remember the trademark so well. After all, an everyday clothing item is more likely to be confused with a similar item in a wardrobe than a fashionable design. ${ }^{33}$ Nevertheless, in Risthaus' view, the protection of trademark owners' investments in marketing and branding campaigns must override the empirical fact that consumers are perhaps less likely to be confused. ${ }^{34}$

Admittedly, information with strong associative links is more likely to be revoked when identifying and interpreting the incoming stimuli. ${ }^{35}$ For confusion between signs, there must be some familiarity with the trademark. If the trademark is not known, there will be no confusion. ${ }^{36}$

\footnotetext{
32 van de Kamp (1999), p. 101. See for some older Dutch cases where the court ruled that the more known the trademark, the sooner the consumer will notice differences between signs: Court of Appeal of The Hague, judgment of 22 May 1933, confirmed by the Supreme Court, judgment of 11 July 1933, NJ 1933, p. 1702; BIE 1933, p. 102 (Aspirin); Court of Appeal of Leeuwarden, judgment of 17 April 1957, BIE 1959, No. 16 (Vredestein); and Court of Appeal of The Hague, judgment of 15 March 1967, BIE 1969, No. 102 (Bayer).

${ }^{33}$ Risthaus (2007), p. 92.

${ }^{34}$ However, the mere association that the public might make between two trademarks as a result of their analogous semantic content does not in itself provide sufficient grounds for concluding that there is a likelihood of confusion. The decisive factor is whether there is a risk of direct or indirect confusion among consumers. See CJEU, judgment of 11 November 1997, case C-251/95 (Puma/Sabel), para 26. Trademarks with a reputation can nevertheless be protected when the signs simply call to mind the protected mark, i.e. whenever there is a link between the signs, but then we are speaking of goodwill protection, not of protecting the origin function of the trademark. (See Art. 10(2) TMD and Art. 9(2)(c) EUTMR. See CJEU, judgment of 23 October 2003, case C-408/01 (Adidas/Fitnessworld), para 29; judgment of 18 June 2009, case C-487/07 (L'Oréal/Bellure), para 36.) Rather than being based on a test of a likelihood of confusion, this excludes any use that takes or might take unfair advantage of, or is or would be detrimental to, the distinctive character or the reputation of a mark, such that these signs are protected against blurring, tarnishment and unfair free-riding (see CJEU, judgment of 18 June 2009, case C-487/07 (L'Oréal/Bellure), paras 34, 39-41).

35 van Horen (2010), p. 20. Jacoby (2001), p. 1035.

${ }^{36}$ Jacoby (2001), pp. 1039-40: "Expectations and context can cause memory to do more than just 'filling in' missing gaps, including ignoring disconfirming information and even 'overwriting' stimuli." Lee et al. found that a brand extension by a competitor of the senior mark increased the likelihood of confusion. For example, consumers are significantly more likely to be confused by the introduction of a "Cadillac" brand notebook computer if they were already exposed to a "Mercedes-Benz" brand entry into that market. Under these circumstances, more sophisticated consumers (for example, consumers who were familiar with the mark) were more likely to be confused because they were better able to perform the cognitive processes necessary to make a connection between the two marks. See Lee, DeRosia, Christensen (2008), pp. 948-499.
} 
However, because of their strong associative network, famous trademarks are much better stored in memory than weak trademarks, ${ }^{37}$ such that differences between signs are more likely to be noticed. ${ }^{38}$ According to Femke van Horen, it is rather risky to imitate highly distinctive elements, not only because of the risk of legal proceedings, but because consumers might evaluate a similar product negatively due to the awareness of the insincere tactics used by the competitor:

Given that extreme standards are more likely to be used as a comparison standard than are moderate standards, it is also likely that contrast will emerge when an extreme leader brand (standard) is imitated (e.g., Coca-Cola). Imitation of an extreme leader brand will immediately bring a distinct image of the leader brand directly to mind, independent of comparison mode. When the imitated leader brand is moderate however (e.g., Elsève shampoo), a less distinct leader will be brought to mind. This implies that it would be more effective for copycats to imitate moderate standards (weaker brands) than extreme standards (stronger brands). ${ }^{39}$

Foxman et al. also pointed out that consumers are more easily confused when their familiarity, experience and involvement with the product are low. ${ }^{40}$ In an experiment, consumers were asked which of their particular products were related to the original brand. Two brands were investigated: the decongestant brand, which was a regionally distributed dealer brand and which was not very well known, and the ramen noodle soup brand, which was a nationally distributed manufacturing brand. More incorrect answers were given with respect to the less known decongestant brand.

Furthermore, consumer perception depends on the consumer's goals. Attention is necessary to achieve a particular goal. Depending on the goal, some information will be processed and other information will not. Attention will be afforded to information that is important for the consumer's decision process. If the consumer has a specific purpose in mind, his or her attention will not only be selective but, in addition, only specific associations that are related to this purpose will be evoked from memory. Depending on the consumer's goal, attention will be focused on the particular aspect of the product representing this goal and associations will be made accessible that fit in with this goal. If the consumer's goal is to buy a branded product, for instance Adidas clothing because of the fashionable stripe motif, the three-stripe motif will be easily recalled from memory. At the moment that the

\footnotetext{
37 See Szmigin and Piacentini (2015), pp. 136, 144-145, 178; Lee (2002), pp. 440-454.

38 In Kimberlee Weatherall's view, it is unlikely that consumers' memories are reflecting the hypothetical state of the EU consumer's mind. If a mark is famous, consumers' memories may be perfect (Weatherall (2017), p. 75; fn. 113). Furthermore, according to Oneto and Sundie, counterfeit products may have limited social value, since those in the know (the wealthier consumers: parvenus and patricians) are likely to perceive counterfeit goods to be of inferior quality and judge counterfeit consumers accordingly. However, the quality of counterfeit products has increased greatly and the sophistication needed to distinguish counterfeit from original products has increased. See Szmigin and Piacentini, p. 192; Oneto and Sundie (1999), pp. 147-182; Han, Nunes, Drèze (2010), pp. 15-30; Gentry et al. (2006), p. 254.

39 van Horen (2010), p. 133.

${ }^{40}$ Foxman et al. (1990), pp. 170-189.
} 
three-stripe motif is important to the consumer, the stripe motif will draw the consumer's attention and be noticed. The consumer will be highly involved and the information surrounding the stripe motif will be processed properly. ${ }^{41}$

The CJEU ruling that states that the more distinctive the trademark, the greater the likelihood of confusion, is thus doubtful. The more distinctive the trademark, the better the trademark is stored in memory. Consumers are more likely to notice differences between distinctive elements than non-distinctive elements. The underlying idea of granting broader protection to known marks is that brand owners would otherwise be penalised because consumers are likely to know every single detail of the brand:

Hinter dem fingierten Einfluss der Kennzeichnungskraft auf die Verwechslungsgefahr steht folglich gerade nicht der Schutz des Verbrauchers vor tatsächlichen Verwechslungsgefahren. Vielmehr liegt diesem Prinzip der Gedanke des Leistungsschutzes zu Grunde. Der Markeninhaber soll durch die Gewährung eines größeren Schutzumfangs für die unternehmerische Leistung belohnt werden, die in der Auswahl einer von Haus aus besonders unterscheidungskräftigen Marke oder im kosten- und benutzungsintensiven Ausbau einer "normalen" Marke zu einer kennzeichnungsstarken Marke verkörpert ist. [...] Der $E u G H$ hat durch dieses Dogma daher schon selbst normative Elemente in die Bestimmung der Verwechslungsgefahr eingeflochten. ${ }^{42}$

In other words, the CJEU's assumption that the more distinctive the trademark the greater the likelihood of confusion is not a rule of fact, but rather serves a normative purpose: to protect the trademark owners' high investments in marketing and branding campaigns. The CJEU's ruling is thus a legal fiction that replaces empirical proof to protect highly distinctive trademarks. ${ }^{43}$ The likelihood of confusion decreases the more distinctive and well known the trademark is.

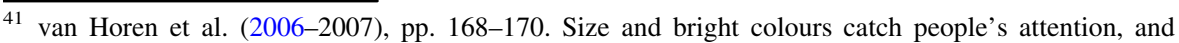
people are sensitive "to stimuli that contrast with their background which are unusual or unexpected". Desai (2018), p. 143; Hughes (2015), p. 1253; Creusen and Schoormans (2005), pp. 64-68. See also Veryzer and Hutchinson (1998), pp. 374-394; Bloch (1995), pp. 16-29; Solomon et al. (2008), pp. 88-89; Celsi and Olson (1988).

42 Seibt (2002), p. 470. See also Kur and Senftleben (2017), p. 326; Ströbele (1991), p. 827: “Je besser eine Kennzeichnung dem Verkehr bekannt sei, desto geringer sei die Gefahr, bei Wahrnehmung einer anderen Erscheinung in den Irrtum zu geraten, die bekannte Marke vor sich zu haben. Insoweit könne der von der Rechtsprechung aufgestellte Satz, verkehrsbekannte Zeichen seien in besonderem Maße Verwechslungen ausgesetzt, jedenfalls in dieser Allgemeinheit nicht anerkannt werden. Andererseits besteht allgemeine Übereinstimmung darin, daß die ständige Spruchpraxis zur Verwechslungsgefahr bei starken und schwachen Zeichen im Ergebnis beizuhalten ist, weil ansonsten der rechtspolitisch unhaltbare Zustand einträte, daß gerade kennzeichnungsschwachen, unbenutzten Zeichen ein weiterer Schutzbereich zugesprochen würde als gut eingeführten Marken, die in besonderer Weise des zeichenreichtlichen Schutzes bedürfen."

43 Sakulin (2011), p. 248; Albrecht (1999), pp. 58-59: "Nach der Gegenmeinung ist die Verwechslungsgefahr um so geringer, je deutlicher die Marke im Erinnerungsbild des Verbrauchers haftet, weil dieser Abweichungen dann eher wahrnimmt. § 8 Abs. 1 Ziff. 3 MarkenG, Art. 4 Abs. 3 und 4 Markenrichtlinie sowie die Einbeziehung der gedanklichen Verbindung zeigen allerdings eine gesetzgeberische Entscheidung zu Gunsten der älteren Marke.”
} 
However, the CJEU applies a normative correction to offer more protection for highly distinctive marks while at the same time refusing to consider the need to keep free for competitors (no normative corrections in favour of competitors). This may create dysfunctional incentives for traders to invest in marketing and branding campaigns concerning design elements that are better kept free for competitors. Exclusive rights on stripe motifs could impede competition because stripe motifs optimise the appearance of sports clothing. Trademark owners are therefore granted a competitive advantage from the sign as such. ${ }^{44}$ The assumptions of the CJEU could thus be an additional facilitating factor that allows trademark owners to monopolise signs. While the CJEU may believe that public interest considerations are unrelated to the likelihood-of-confusion assessment because the assessment is allegedly based on the public's perception, in reality the public's perception is not leading when it concerns highly distinctive marks. The anti-confusion assessment is therefore imbalanced and may generate dysfunctional incentives.

\section{National Case Law}

In ruling in the Adidas/Marca case that the need to keep signs free is not a relevant factor in confusion cases, the CJEU seems to have opted for a more investmentbased approach. To explore whether national case law changed following Adidas/ Marca, several cases surrounding the three-stripe motif of Adidas were investigated. The Adidas cases are of particular interest in this context because they all contain the same questions concerning the likelihood of confusion and the need to keep signs freely available. The debate in each case centred on whether a specific stripe motif on clothing (the two/four-stripe motif) was similar to the Adidas trademark (the three-stripe motif).

In some countries, the legal position of third parties may not have changed since Adidas/Marca. In Germany and in France, cases can be found where national courts specifically rewarded Adidas' high investments in marketing and branding campaigns involving the three-stripe motif. In these cases, national courts highly emphasised the notoriety of the brand and the resulting likelihood of confusion among consumers while freedom-of-competition arguments were found irrelevant.

For example, in Germany, the Cologne Higher Regional Court ${ }^{45}$ had already ruled in 2005 (prior to the Adidas/Marca case in 2008) that Nike's sports trousers bearing two parallel white stripes on the outside of the legs and the well-known "swoosh" trademark were an infringement on the three-stripe mark of Adidas.

Given the highly distinctive character of the three-stripe mark, consumers would interpret the defendant's two stripes as an indication of origin, not as mere decoration. The swoosh trademark on the clothing would not preclude the stripes from also functioning as a trademark. ${ }^{46}$ In addition, there was at least average

\footnotetext{
${ }^{44}$ Max Planck Institute (2011), p. 52.

${ }^{45}$ Cologne Higher Regional Court, judgment of 16 December 2005, case 84 O 74/05, [2006] E.T.M.R. 37, Adidas-Salomon AG v. Nike International Ltd and Nike Retail BV.

${ }^{46}$ Ibid., paras 11-12.
} 
similarity between the signs. The swoosh was a purely figurative sign of inconspicuous size, such that the consumer would not perceive it as a dominant sign. Furthermore, a substantial number of consumers would not even see the swoosh when it was covered by a matching jacket. ${ }^{47}$ Therefore, according to the Cologne Higher Regional Court, consumers were likely to be confused. ${ }^{48}$

Therefore, freedom-of-competition arguments were overruled by investmentbased arguments. Stripe patterns may primarily be seen as decoration, but after high investments in marketing and branding the three-stripe motif, the court said, consumers would perceive it as a source identifier and no longer as pure decoration. ${ }^{49}$ According to the court, similar stripe motifs would be perceived in the same way. The court did not further discuss the argument that third parties may also need similar stripe motifs to decorate their products.

In the same year, the Munich Higher Regional Court ${ }^{50}$ also ruled that a likelihood of confusion existed. The defendant Dolce \& Gabbana sold black trousers made from stretch material embellished with two silver stripes on both sides. The trousers had a buckle with the trademark "D\&G" on the waistband and one on a rear pocket.

Again, the judge concluded that consumers would perceive the stripes as a trademark. Because of the notoriety of the Adidas brand, the public was used to seeing an indication of origin in stripes on both sides of clothing. Consumers were also accustomed to secondary signs in addition to a famous mark. Moreover, consumers would not always see the $D \& G$ logo, for example when viewed from the side. ${ }^{51}$ The notoriety of the three-stripe motif was again a decisive factor in the likelihood-of-confusion assessment:

In view of the exceptionally high distinctive character of the claimant's marks and of the substantial proximity of goods - which results in comprehensive protection with respect to a trade mark only enjoying average distinctive character with the consequence of the necessity of a greater distance between signs to avoid a trade mark infringement - the differences in the two conflicting signs are not sufficient to preclude the likelihood of confusion. [...] Moreover, experience has shown that signs of a distinctive character, in particular famous signs, will tend to be remembered more. The addressed public will therefore also tend to believe it recognises such signs it is familiar with in a different sign. ${ }^{52}$

\footnotetext{
47 Ibid., paras 13-14.

${ }^{48}$ Ibid., paras 16-17. See also the Cologne Regional Court, which similarly argued that a likelihood of confusion existed. Because of the notoriety of the three-stripe motif, the consumer would perceive the two-stripe motif as a trademark and not as embellishment. The "swoosh" mark did not prevent the likelihood of confusion among consumers. First, the swoosh was less eye-catching than the stripes. Second, consumers might believe that Nike and Adidas were in co-operation (Cologne Regional Court, judgment of 20 January 2005, case 840 74/04, [2005] E.T.M.R. 91, Adidas-Salomon AG v. Nike International Ltd and Nike Retail BV, paras 21-22).

49 Cologne Higher Regional Court, judgment of 16 December 2005, case 84 O 74/05, [2006] E.T.M.R. 37, Adidas-Salomon AG v. Nike International Ltd and Nike Retail BV, para 8.

50 Munich Higher Regional Court, judgment of 10 November 2005, case 29 U 2238/05, [2006] E.T.M.R. 38, Adidas-Salomon AG v. Dolce \& Gabbana Germany GmbH, Alfonso Giuseppe Dolce.

51 Ibid., paras 21-26.

52 Ibid., para 30.
} 
Furthermore, the Munich Higher Regional Court explicitly rejected that the need to keep free should be taken into account:

The examination of conflict under trade mark law does not provide for a need to keep free. Outside the scope of Art. 23 of the [German] Trade Mark Act which is not central here - the fact applies in infringement proceedings that the trade mark proprietor can take proceedings against uses of signs capable of confusion using the standard of the provision of trade mark law while asserting its monopoly position by the trade mark protection. ${ }^{53}$

In other words, the Munich Higher Regional Court adopted the exact same approach as the CJEU in the Adidas/Marca decision. In the Adidas/Marca case, the CJEU ruled that the need for a sign to be freely available for competitors was not a relevant factor in the likelihood-of-confusion assessment. Although the limitations and exceptions under Art. 14(1)(b) TMD gave expression to the requirement of availability, in the CJEU's view, the likelihood-of-confusion provision did not. The CJEU further argued that the requirement of availability could only restrict the effect of the trademark if this was expressly provided for in the limitations and exceptions under Art. 14(1)(b) TMD. With regard to the purely decorative nature of the competitors' two-stripe motifs at issue, the CJEU ruled that this use was not intended to give an indication concerning one of the specified characteristics of the goods and was therefore not allowed. ${ }^{54}$ In the same way, Art. 23 of the German Trade Mark Act, which prescribes defences for descriptive use, was probably not applicable. It therefore can be said that the Munich Higher Regional Court's decision basically anticipated the CJEU's later ruling.

In an earlier case, the Munich Regional Court also referred to the exceptionally high degree of distinctiveness of Adidas' three-stripe motif in the Adidas/C\&A case. ${ }^{55}$ The court concluded that everyone's awareness of the claimant's trademark could be assessed by the court from its own knowledge, such that market studies were not necessary. The notoriety of the brand was a generally known fact. ${ }^{56}$ Nevertheless, a survey showed that $91.3 \%$ of market participants are aware of the three-stripe motif these days. ${ }^{57}$ The court also emphasised the normative concept of the likelihood-ofconfusion assessment but did not mention the need to keep free in this perspective:

However, the claimants correctly point out that the examination of the legal concept of the risk of confusion does not mean a decision which forecasts whether consumers reach the assumption that they would purchase Adidas

\footnotetext{
53 Ibid., para 32. See also Munich Higher Regional Court, judgment of 12 February 2004, case 26 U 5518/03, [2005] E.T.M.R. 2, Adidas Salomon AG v. Dolce \& Gabbana Germany GmbH, paras 12-15, which also argued that a likelihood of confusion existed. In this case, the judge also emphasised the notoriety of the brand, and held that the three-stripe motifs would be "exceptionally well-known marks, which is an obvious fact" (para. 14) and "[i]n view of the extremely high identifying power of the applicant's marks and the similarity of the goods, which is at least close, the differences in the two marks are not capable of eliminating the risk of confusion" (para. 15).

54 CJEU, judgment of 10 April 2008, case C-102/07 (Adidas/Marca), paras 47-48.

55 Munich Regional Court, judgment of 26 July 2001, [2004] E.T.M.R. 3, Adidas AG v. C \& A Mode Co.

56 Ibid., para 50.

57 Ibid., para 53.
} 
products if they faced the attacked design, because solely a normative determination of the distance to be kept from the older design is involved. ${ }^{58}$

The Munich Regional Court thus explicitly chose to reward Adidas' high investments. In the Adidas/Marca case, the CJEU rejected the need for signs to be freely available by saying that the likelihood-of-confusion assessment must be based on consumer perception. ${ }^{59}$ Contrary to the Adidas/Marca case, the Munich Regional Court admitted that consumers were not necessarily confused. Instead of hiding behind consumer perception rationales, the Munich Regional Court stated that its decision represented a normative determination of the desirable distance between parties on the market. Freedom-of-competition arguments were however not discussed. Because of the high awareness of the trademark, the court said consumers would perceive the stripe motif as an origin indication and not as a mere adornment. ${ }^{60}$ It can be concluded that this case too was based unilaterally on trademark proprietors' interests.

Adidas was also successful in France, in the Cour d'Appel de Paris. ${ }^{61}$ The defendant had produced jackets bearing three parallel stripes in the same position, as well as along the waist and collar, together with the words "Navy", "Taille Crayon" and "TC", and a red and blue flag on the garments, with the addition of the words "Taille Crayon Atlantic Dream" on a label inside the garment. The trousers were embellished with two stripes along the side of the leg. According to the Cour d'Appel de Paris, the textual inscriptions, which were fantasy words, did not eliminate the risk of confusion. First, Adidas itself often used inscriptions on its clothing. Second, the risk of confusion would be greater since the consumer was particularly familiar with the three-stripe motif. ${ }^{62}$ Again, freedom-of-competition arguments were not discussed in this case.

The German and French cases illustrate that prior to Adidas/Marca, the courts' arguments were already biased in favour of trademark owners' interests. While the consumers' factual perception was not decisive, assumptions on how consumers ought to behave did play a central role. The leading principle in these cases was that consumers were more likely to be confused because of the notoriety of the brand. As pointed out before, from an empirical perspective, the notoriety of the brand should rather be seen as a counter-argument that undermines the conclusion that a likelihood of confusion exists. Consumers are less likely to be confused, the more distinctive the trademark is. Under the umbrella of consumer perception, the German and French courts were actually protecting Adidas' investments. They did so not only by emphasising the notoriety of the brand and disregarding how consumers factually perceived signs, but also by bypassing freedom-of-competition arguments. In some cases, these courts explicitly ruled that freedom-of-competition interests were not relevant in the likelihood-of-confusion assessment; in other cases, they were simply ignored. These cases can be seen as precursors of the Adidas/

\footnotetext{
58 Ibid., para 59.

59 CJEU, judgment of 10 April 2008, case C-102/07 (Adidas/Marca), para 30.

${ }^{60}$ Munich Regional Court, judgment of 26 July 2001, [2004] E.T.M.R. 3, Adidas AG v. C \& A Mode Co., para 59.

61 Cour d'Appel de Paris (4th Chamber, Section A), judgment of 3 March 2004, [2005] E.T.M.R. 4, Adidas Sarragan France v. Subo, Bauer.

62 Ibid., para 7.
} 
Marca decision in 2008; an investment-based approach that perhaps already began with the Puma/Sabel decision.

However, there are also national systems where a clear reversal can be seen following Adidas/Marca. For example, in the Netherlands, courts indeed seem to have followed a more investment-based approach since Adidas/Marca. In the most prominent case, in 2017, the District Court of The Hague concluded that H\&M's two-stripe motif used for sports clothes infringed on Adidas' three-stripe motif. ${ }^{63}$

In this case also, the court focussed on the trademark's highly distinctive character. According to the court, the three-stripe motif was well known among a significant portion of the relevant public: $80 \%$ in $1995,84 \%$ in $2004,78 \%$ in 2007 , $61 \%$ in 2012 , and $76 \%$ in $2015 .{ }^{64}$ Examples were presented of catalogues, sales data, marketing budgets, market studies, and information on the size of the company's sponsoring activities. A market study of the defendant H\&M also demonstrated that the three-stripe motif was well known.

Furthermore, the court argued that the two-stripe sign of H\&M was visually highly similar to the three-stripe motif of Adidas. In the two-stripe sign, seven out of eight distinctive parts of the three-stripe mark could be found. ${ }^{65}$ The only difference was that two instead of three stripes were used. The number of stripes was not the most distinctive part of the three-stripe mark; rather the eight features were together responsible for the overall impression of the trademark.

The court further assumed a relevant public that consisted of consumers of everyday products, such as sports and leisure wear. This consumer would not be highly attentive when purchasing such clothing, and the court took as a benchmark the average consumer who is reasonably well informed, observant, and circumspect. ${ }^{66}$

Both parties supported their arguments with market studies on the likelihood of confusion, and both studies were criticised. The court left the critical comments to the side and concluded that the outcome of both studies supported the assessment that a likelihood of confusion existed. According to the court, percentages of $24 \%$ and $34 \%$ of confusion on the origin of the products were significant. The court consequently concluded that H\&M infringed on the rights of the trademark owner Adidas. ${ }^{67}$

In this case, the court was therefore clearly focused on the trademark owner's high investments. The court ruled that the distinctive character was high, which was supported by empirical facts. Consumers would be confused when confronted with

\footnotetext{
${ }^{63}$ District Court of The Hague, judgment of 8 November 2017, ECLI:NL:RBDHA:2017:12949 (Adidas/ $H \& M)$. For a similar outcome of a previous case in the proceedings, see Court of Appeal of ArnhemLeeuwarden, judgment of 1 December 2015, case 200.135.172/02, IER 2016/31.

64 Ibid., paras 4.21-4.22.

65 The court noted that the trademark of Adidas consists of a motif of (1) three, (2) vertical, and (3) parallel stripes, of (4) equal width, in which (5) the gap between the stripes is visually more or less the same width as the stripes, and (6) the stripes are of the same colour, (7) which contrasts with the basic colour of the garment. The stripes are also always applied (8) along the entire length of the side of the shoulders, sleeves, side seams and/or trouser legs of a garment. According to the court, the discussion was not only about three stripes, but about a trademark consisting of these eight distinctive elements.

${ }^{66}$ District Court of The Hague, judgment of 8 November 2017, ECLI:NL:RBDHA:2017:12949 (Adidas/ $H \& M)$, para 4.20 .

${ }^{67}$ Ibid., paras 4.31-4.37.
} 
similar stripe motifs because of the brand's notoriety. Moreover, a market study of the likelihood of confusion also supported the decision. Normative considerations on the need to keep this specific stripe motif freely available for other competitors were not mentioned. Adidas' efforts in marketing campaigns paid off.

Remarkably, prior to Adidas/Marca, decisions can be found in which Dutch courts expressed a strong preference for freedom-of-competition arguments.

For example, in 2005, the Court of Appeal of 's-Hertogenbosch ${ }^{68}$ ruled that H\&M did not infringe Adidas' trademark rights. Despite pointing out that the threestripe motif was well known and therefore had a broad scope of protection, the judge emphasised that this did not mean that Adidas could also prohibit other stripe motifs. According to the court, stripes and simple stripe motifs are not signs that are amenable to far-reaching monopolisation; they are common and must therefore be freely available to third parties, even when one specific stripe motif has acquired a strong distinctive character through use in trade.

The judge admitted that some similarity between the trademark and the sign existed. However, according to the judge, the differences between the trademark and the sign were not marginal but essential because they would directly attract the attention of the consumer. The Adidas trademark consisted of three stripes, while the H\&M stripe motif had two. This eye-catching - and thus essential - difference, hindered the sign from being seen as confusingly similar to the trademark. ${ }^{69}$ Therefore, infringement could not be assumed. ${ }^{70}$ In this case the judge thus explicitly referred to the need for competitors to freely use similar signs on the market.

In 1999, the Court of Appeal of 's-Hertogenbosch ${ }^{71}$ had also ruled that there was no likelihood of confusion between the two stripes of H\&M and the three stripes of Adidas. The judge argued that the average consumer of sports and leisure clothes was a smaller group than the average consumer. This group would sooner notice the distinction between the trademark and the sign, the pricing difference between $\mathrm{H} \& \mathrm{M}$ and Adidas (cheap versus expensive, respectively), the sales outlets of the clothes (H\&M stores carry exclusively H\&M products), the familiarity of the Adidas trademark, and the distinctive character of the trademark and the sign. ${ }^{72}$

\footnotetext{
${ }^{68}$ Court of Appeal of 's-Hertogenbosch, judgment of 29 March 2005, ECLI:NLGHSHE:2005:AT2596, BIE 2005, 82 (Adidas/Marca c.s. and H\&M).

69 Ibid., para 4.20.

70 Ibid., para 4.21. The judge also did not refer to market studies. Ibid., paras 4.22-4.24. Market studies were assessed under Art. 2.20(1)(c) of the Benelux Convention on Intellectual Property (BCIP) concerning trademarks with a reputation. The court of appeal, however, rejected the market studies because they could not prove that an economic link existed at the moment the infringement took place, namely in 1996.

71 Court of Appeal of 's-Hertogenbosch, judgment of 8 June 1999, case C9700988/BR (H\&M/Adidas).

72 Ibid., paras 4.11-4.12. The court of appeal had postponed the case in 1999 because of preliminary questions. In 2005, the same court of appeal ruled that the answers to the preliminary questions did not lead to a different outcome. According to the CJEU, association between the sign and the trademark is not sufficient to conclude a likelihood of confusion even in cases of a well-known mark. The likelihood of confusion needs to be positively affirmed. See Court of Appeal of 's-Hertogenbosch, judgment of 29 March 2005, ECLI:NL:GHSHE:2005:AT2596 (Adidas/Marca c.s. and H\&M), para 6.5; CJEU, judgment of 22 June 2000, case C-425/98 (Marca/Adidas), para 41. See also Benelux-Gerechtshof, 7 June 2002, ECLI:NL:XX:2002:AG7751, NJ 2003, 426 (Marca/Adidas), para 41.
} 
The fact that the trademark was well known did not lead the court to conclude that a likelihood of confusion existed. Rather, the court seemed to interpret the notoriety of the Adidas trademark as implying that consumers would not be confused. ${ }^{73}$ Besides, the judge argued that the results of the surveys in Belgium and Germany were insufficiently targeted and did not provide a decisive answer as to the likelihood of confusion. ${ }^{74}$

Here we see that the factual circumstances meant that no likelihood of confusion existed. The judge decided not to take the consumer of everyday products as a benchmark, but rather a more brand-conscious consumer who is interested in sports and leisure clothes. This allowed the judge to give greater importance to freedomof-competition arguments.

In 1998, in the Fitnessworld/Adidas case ${ }^{75}$ the Court of Appeal of Arnhem also interpreted the relevant public as consumers who are more attentive than average. According to the judge, the relevant segment of the Adidas public are people who wish to be seen in exclusive and more expensive clothes. This public knows that Adidas uses a three-stripe motif and will therefore not be confused when confronted with clothes with two stripes attached in the same place, such as the Fitnessworld clothes. They will easily see the difference between two and three stripes, especially when purchasing clothes, because this is not as a rule done hastily or thoughtlessly. $^{76}$

In addition, the court of appeal believed that, considering the overall impression, the three stripes were a distinctive and dominant element. Furthermore, it believed that Adidas tried to monopolise the stripes motif with its trademark. This monopolisation on the part of Adidas was not allowed in this case, in which the twostripe motif was seen as a decorative feature and not a trademark, and the clothes

\footnotetext{
73 It was to be expected that the court of appeal would rather emphasise the reputation of the three-stripe motif, the high investments of Adidas, the similarity of the goods, and the similarity of the signs, and therefore conclude that a likelihood of confusion existed. These considerations, however, are reminiscent of the Picasso/Picaro case, in which the CJEU also ruled that the average consumer could have a particularly high level of attention at the time of purchasing the goods because of the nature of the goods in question - especially their price and highly technological character. A high level of attention could reduce the likelihood of confusion. The possibility that the consumer may on occasion have a lower level of attention - for example, when confronted with a sign unconnected with the act of purchase - was not relevant in this respect because "the existence of such a possibility does not prevent the taking into account of the particularly high level of attention exhibited by the average consumer when he prepares and makes his choice between different goods in the category concerned". See CJEU, judgment of 12 January 2006, C-361/04 P (Picasso/Picaro), paras 39-41.

74 Furthermore, although H\&M argued that the two stripes were used merely decoratively, the judge ruled that this use must be weighed against Adidas' use. Adidas had a right to protect its trademark because of the registration and the highly distinctive character that the trademark had acquired through intensive marketing campaigns. In other words, the judge explicitly recognised that the need to keep signs freely available should be weighed against the rights of the trademark owner. Court of Appeal of 'sHertogenbosch, judgment of 29 March 2005, ECLI:NLGHSHE:2005:AT2596, BIE 2005, 82 (Adidas/ Marca c.s. and $H \& M)$, para 4.6.

75 Court of Appeal of Arnhem, judgment of 18 August 1998, ECLI:NL:GHARN:1998:AK2233 (Fitnessworld/Adidas). See also Supreme Court, judgment of 12 October 2001, ECLI:NL:PHR:2001:ZC3688 (Adidas/Fitnessworld); CJEU, judgment of 23 October 2003, case C-408/ 01 (Adidas/Fitnessworld).

76 Ibid., para 5.10 .
} 
considered had the trademark "Perfetto" in almost all cases. ${ }^{77}$ This shows that, contrary to the Adidas/H\&M case in 1999, the judge more explicitly considered that the interest in the need to keep free must outweigh the interests of the trademark owner Adidas.

In 2006, Adidas lost against one of its big competitors in sports clothing: Nike. A strong preference for the need to keep free was evident. The District Court of The Hague $^{78}$ ruled that the public would interpret the two-stripe motif of Nike as a decorative feature and not as a trademark. The judge set aside Adidas' evidence showing that consumers recognised the two-stripe motif as a trademark. In the court's opinion, Adidas had insufficiently refuted Nike's criticism of the market studies. $^{79}$

But even if a small proportion of the relevant public recognised the two stripes as a trademark, according to the judge, particular decorative elements must remain freely available. ${ }^{80}$ Despite Adidas' arguments, the judge considered that this was a factor that must be taken into account not only when assessing whether the trademark was suitable for registration, but also when determining the scope of protection. According to the judge, it would be in conflict with the system developed by the CJEU in the cases Chiemsee, Linde and Libertel ${ }^{81}$ - among others - not to weigh the need to keep signs freely available in the infringement assessment. ${ }^{82}$ In the Court's logic, if that were the case, a trademark owner could then prohibit the use of a sign through expanding the scope of protection which would normally not be registered because of reasons of general interest. ${ }^{83}$

The district court also argued that the average consumer when confronted with the two-stripe motif would neither think of Adidas nor presume that the clothes belong to Adidas. Two stripes could be very easily distinguished from three.

\footnotetext{
${ }_{77}$ Ibid., para 5.11.

${ }^{78}$ District Court of The Hague, judgment of 5 July 2006, ECLI:NL:RBSGR:2006:BA8987 (Adidas/ Nike).

${ }^{79}$ Ibid., para 4.5 .

${ }^{80}$ Ibid., para 4.8 .

${ }^{81}$ CJEU, judgment of 4 May 1999, case C-109/97 (Chiemsee); CJEU, judgment of 8 April 2003, case C-53/01-55/01 (Linde); CJEU, judgment of 6 May 2003, case C-104/01 (Libertel).

${ }^{82}$ In the Windsurfing Chiemsee case, the CJEU explicitly recognised that descriptive signs or indications relating to categories of goods or services need to remain freely available because "it is in the public interest that they remain available, not least because they may be an indication of the quality and other characteristics of the categories of goods concerned, and may also, in various ways, influence consumer tastes by, for instance, associating the goods with a place that may give rise to a favourable response". (CJEU, judgment of 4 May 1999, case C-108/97, C-109/97 (Windsurfing Chiemsee), para 26.) See also the conclusion of Advocate General Jacobs, para 63, case C-408/01 (Adidas/Fitness World).

${ }^{83}$ According to current EU trademark law, non-distinctive signs can acquire distinctiveness through use in trade: "Where signs are not inherently capable of distinguishing the relevant goods or services, Members may make registrability depend on distinctiveness acquired through use." (Art. 4(4) Trademark Directive, Art. $6^{\text {quinquies }}(\mathrm{C})(1)$ Paris Convention and Art. 15(1) TRIPS Agreement.) See also CJEU, judgment of 4 May 1999, cases C-108/97, C-109/97 (Windsurfing Chiemsee), paras 44-45). Unlike absolute grounds for refusal based on public policy or principles of morality and signs of high symbolic value, which cannot be overruled by demonstrating acquired distinctiveness through use in trade, nondistinctive, descriptive and generic signs can be registered if consumers perceive these signs as a badge of origin.
} 
Furthermore, a consumer who was reasonably well informed could not be expected to be led exclusively by the two stripes. He would try to find out whether the clothes were indeed from Adidas, if the company came to his mind. Because of the familiarity of the three-stripe mark, when faced with two instead of three stripes, the consumer would more quickly question whether Adidas was involved with the origin. As soon as the consumer found out whether the hunch that the clothes might be from Adidas was right, however, he would immediately see the well-known Nike swoosh.

According to the district court, it was inconceivable that the relevant public would think that Adidas and Nike could be economically related. An average consumer could not miss the fact that the two companies were major rivals. This fact, combined with the difference in the number of stripes, would distract the consumer from the thought that the companies could be economically related. According to the district court, there was no likelihood of confusion even if the consumer thought of Adidas.

Moreover, expert studies also did not point to a likelihood of confusion. ${ }^{84}$ The interests of a third party to freely use a similar sign for similar goods therefore outweighed the interests of the trademark owner Adidas. ${ }^{85}$

Contrary to the German court, the Dutch court left the way open for making normative corrections in favour of freedom-of-competition arguments. In the German case, the CJEU's ruling of granting more protection the more distinctive the trademark is could not be set aside, not even by the fact that the two-stripe motif was combined with the highly well-known Nike swoosh mark. Trademark proprietors' interests were dominant. The German court found the swoosh a purely figurative sign of inconspicuous size, such that the consumer would not perceive it as a dominant sign. A matching jacket would also hide the swoosh mark. In contrast to the swoosh mark, Nike's two-stripe motif would be perceived by consumers as an indication of origin, not as a mere decoration.

In the Dutch case, however, the court argued the other way around: the two-stripe motif of Nike was simply seen as a decorative feature. Furthermore, the court explicitly indicated that even if some consumers perceived the two-stripe motif as a trademark, freedom-of-competition arguments should outweighed trademark owners' rights. In addition, the Dutch court stated that the notoriety of the Nike swoosh would prevent a likelihood of confusion.

In other words, both cases involved normative corrections: in the German case, normative corrections were made in favour of trademark owners' high investments; in the Dutch case, normative corrections in favour of third parties' need to keep signs freely available were decisive. However, the Dutch case particularly differed

\footnotetext{
${ }^{84}$ District Court of The Hague, judgment of 5 July 2006, ECLI:NL:RBSGR:2006:BA8987 (Adidas/ Nike), paras 4.9-4.10.

85 For a contrary result, see the District Court of Amsterdam, judgment of 8 June 2006, ECLI:NLRBAMS:2006:BB7942 (Adidas/Scapa); Court of Appeal of Amsterdam, judgment of 8 November 2007, ECLI:NL:GHAMS:2007:BB7456 (Scapa/Adidas). It can be assumed that a competitor such as Nike does not need to profit from Adidas' reputation. Nevertheless, Nike will not have chosen accidentally to bring its clothing onto the market with a similar sign. Nike can harm Adidas' reputation by deliberately using a similar stripes mark.
} 
from the German case in that the court explicitly stated that normative corrections were justified without making assumptions about consumer perceptions alone.

Lastly, in Denmark, one can also find decisions seeking to offer room for freedom-of-competition arguments which preceded the CJEU decision in Adidas/ Marca. The Højesteret (high court) ${ }^{86}$ ruled that the third party's sign was not confusingly similar to the three-stripe motif of Adidas. ${ }^{87}$ The defendant sold jackets embellished with bands formed by four parallel stripes of equal width and length, and the bands were the same colour as the jacket. In the high court's opinion, consumers would generally know that Adidas' trademark consists of exactly three and not four stripes. Furthermore, according to the high court, the use of stripes on clothes was extremely common, especially on sports and leisure apparel. It was also common to place stripes along the side of the sleeves on a jacket. ${ }^{88}$ The high court clearly followed a freedom-of-competition approach: "When determining the scope of protection for this trade mark, great emphasis must be put on the fact that other companies are not prevented from using stripes to embellish clothes to a further extent than what is necessary in order to protect the trade mark." 89

The Danish high court thus explicitly expressed its concerns regarding the availability of signs on the market. The argument that the use of stripes on clothes was extremely common, especially on sports and leisure apparel, impacted the court's decision. Adidas' high investments in marketing and branding campaigns with respect to the three-stripe motif could not overrule the fact that stripe motifs were extremely common. The likelihood-of-confusion assessment must be viewed in this light.

As shown above, decisions preceding Adidas/Marca were more balanced in the Netherlands and Denmark than those following after the CJEU's Adidas/Marca decision. In the cases following Adidas/Marca, the interests of the trademark owner Adidas were decisive. In these cases, courts ruled that consumers were more likely to be confused because of the notoriety of the brand. However, as pointed out earlier, from an empirical perspective, consumers are less likely to be confused when confronted with a highly well-known mark. Therefore, courts made normative corrections in order to protect Adidas' high investments.

On the other hand, in cases preceding Adidas/Marca, courts also included the interests of third parties in their decisions. In the courts' view, the need for other parties to freely compete with alternative products on the market was more important than the need to protect Adidas' investments and consumers against confusion.

As the cases before Adidas/Marca show, a different world with more room for freedom-of-competition arguments is plausible. Only when judges are able to implement normative corrections in favour of trademark owners as well as third parties is it possible to ensure undistorted, fair and meaningful competition. Because

\footnotetext{
${ }^{86}$ Højesteret (High Court), Second Division, judgment of 24 November 2005, [2006] E.T.M.R. 88, case 361/2001, Adidas International B.V. v. FDB.

87 Ibid., para 72.

88 Ibid., para 70.

${ }^{89}$ Ibid., para 71.
} 
appealing signs are not available in unlimited numbers, exclusive trademark rights on stripe motifs may affect the availability of design elements on the market and hinder competition. Stripe motifs contribute to the style and appearance of sports clothing and therefore give Adidas a competitive advantage from the sign as such. ${ }^{90}$ Therefore, it is also necessary to balance third parties' interests in the likelihood-ofconfusion assessment as the Dutch and Danish courts did before Adidas/Marca, particularly where appealing signs are concerned.

The fact that the German and French courts clearly preferred to reward Adidas' high investments without considering freedom-of-competition arguments makes their decisions less plausible. The more so since in these cases - with the exception of the Adidas $/ C \& A$ case ruled by the Munich Regional Court - courts seem to hide their normative corrections in favour of trademark owners behind the rationales of consumer perception.

The fact that national courts seem to have veered towards a more investmentbased approach, particularly after Adidas/Marca, means other core values may become jeopardised, such as safeguarding freedom of competition and (commercial) freedom of expression. Ideally, therefore, the CJEU should change course and depart from the Adidas/Marca ban on the freedom-of-competition arguments in the infringement analysis.

As a second-best solution, national courts could provide more room for the need to keep free under the current CJEU jurisprudence. The Dutch and Danish cases mentioned above can serve as an example. Within the present legal framework, judges could deviate from the pattern of automatically granting more protection when trademarks are very well known. They can emphasise the factual circumstances of the case, which indicate that consumers are not likely to be confused. Judges can interpret the concept of the average consumer flexibly. Instead of emphasising that the relevant public is the average consumer of everyday products who is not highly attentive - as the District Court of The Hague did in 2017 - judges can also refer to an average consumer who is interested in sports clothes and is therefore highly attentive. Judges could also attach less value to consumer studies, particularly when the outcome of these studies is strongly criticised.

The Picasso/Picaro case ${ }^{91}$ ruled by the CJEU may be used as a reference to make normative corrections in the likelihood-of-confusion assessment. The name "Picasso", highly well known among consumers as a painter, was also used as a trademark for cars. However, because the trademark was not so highly well known among consumers, the judge concluded that consumers would not be likely to be confused when confronted with the similar sign "Picaro", also used for cars. From a

\footnotetext{
90 Max Planck Institute (2011), p. 52.

91 CJEU, judgment of 12 January 2006, case C-361/04 P, ECLI:EU:C:2006:25 (Ruiz-Picasso and Others v. OHIM). See Opinion of Advocate General Ruiz-Jarabo Colomer, judgment of 8 September 2015, ECLI:EU:C:2005:531 (Ruiz-Picasso and Others v. OHIM), para 69: "Secondly, there is a certain general interest in protecting the names of great artists, which represent a universal cultural heritage, from insatiable commercial greed, in order to safeguard their work from trivialisation. It is sad to think that the averagely informed, reasonably aware and perceptive consumer, who no longer links names such as Opel, Renault, Ford or Porsche with the outstanding engineers whose products were named after them, will, unfortunately, in the not-too-distant future be subjected to the same process in relation to the name Picasso."
} 
conceptual perspective, the CJEU found the signs very different. This line of argument could also be used in the case of stripe motifs. Courts could make factual statements about the perception of consumers, for example that consumers usually perceive stripes as a decoration (as the CJEU did in the Picasso/Picaro case, saying that consumers will particularly think of the painter). Under the umbrella of consumer perception, courts could reach a normative purpose, namely safeguarding free access to stripe motifs in the sports sector. ${ }^{92}$

Furthermore, since the EU trademark law reform entered into force, the new limitations on non-distinctive signs might also provide room to consider the rights of third parties. ${ }^{93}$ This defence allows competitors to refer to the non-distinctiveness of the similar sign they use themselves. Competitors might argue that a similar stripe motif (i.e. two stripes) is not inherently distinctive, nor is it used to indicate origin, for example when the clothing bears the defendant's own word mark. ${ }^{94}$ Although the three-stripe motif has acquired distinctiveness through use in trade on the market, the three-stripe motif is also a design item that evokes associations that are inherent to the stripe motif itself. This original meaning should remain freely available for competitors. ${ }^{95}$

However, it remains to be seen whether the new limitation will give competitors more freedom to use stripe motifs. Furthermore, under the new provision, the use of the sign is only justified if it is in accordance with honest commercial practices; a principle that constitutes in substance the expression of a duty to act fairly in relation to the legitimate interests of the trademark owner. ${ }^{96}$ Given the notoriety of the three-stripe motif, using a similar stripe motif on sports clothing will probably be seen as unfairly competing with the trademark owner. ${ }^{97}$ In addition, the use of a similar stripe motif cannot be seen as intended to give an indication concerning one of the specified characteristics of the goods. ${ }^{98}$

The broadening of the limitation rights is very helpful, but it is not sufficient to safeguard third parties' interests. The burden of proof lies with the defendant and the likelihood of confusion is still biased in favour of brand owners. A system where normative corrections can also be made in favour of third parties (like the former Dutch system) is to be preferred to a one-way system in which normative

\footnotetext{
92 See also Senftleben (2018), p. 324. Nevertheless, if courts follow this argument, they must ignore market studies that provide evidence that consumers are highly familiar with stripes and recognise them as a badge of origin. The difference from the Picasso case is that the three-stripe motif is very well known; the "Picasso" trademark for cars is less distinctive. Besides, stripe motifs do not have a clear meaning, while the word mark "Picasso" does have a clear reference to the painter Picasso.

93 Article 14(1)(b) TMD 2015; Art. 14(1)(b) EU Trademark Regulation.

94 See, for example, District Court of The Hague, judgment of 5 July 2006, ECLI:NL:RBSGR:2006:BA8987 (Adidas/Nike). See also CJEU, judgment of 10 April 2008, case C-102/07, ECLI:EU:C:2008:217 (Adidas/Marca), para 48: "In the present case, according to the decision making the reference and the observations submitted to the Court by the competitors of Adidas, the latter rely on the purely decorative nature of the two-stripe motifs at issue to justify their use."

95 See Kur (2018), p. 89.

96 CJEU, judgment of 23 February 1999, case C-63/97 (BMW/Deenik), para 61.

97 See also CJEU, judgment of 7 January 2004, case C-100/02 (Gerolsteiner Brunnen GmbH \& Co), para 26.

98 CJEU, judgment of 10 April 2008, case C-102/07 (Adidas/Marca), paras 47-48.
} 
corrections are automatically made in favour of brand owners. ${ }^{99}$ The present legal framework would be apt to bring normative corrections both in favour of trademark owners and third parties under the umbrella of consumer perception. Ideally, the CJEU would change course and depart from the Adidas/Marca ban on the freedomof-competition arguments in the infringement analysis.

\section{Conclusion}

This article shows that it is necessary to also weigh policy concerns when making the likelihood-of-confusion assessment. Although it sounds empirically plausible to protect consumers against confusion, in reality this anti-confusion claim is based on normative considerations. The CJEU's assumption that consumers are more likely to be confused when confronted with signs that are similar to a highly distinctive trademark is not correct. In fact, it is rather the other way around: the more distinctive the trademark, the less likely that consumers will be confused when confronted with a similar sign.

The consequence is, however, that trademark owners' marketing efforts are rewarded: the more they invest in a particular sign, the more protection they achieve. At the same time, competitors' concerns may be disregarded because of Adidas/Marca.

This is particularly problematic in relation to appealing signs such as stripe motifs. These signs not only serve as a source identifier, but also appeal to consumers and therefore give trademark owners an advantage over competitors on the market. Because Adidas is the only trademark owner that can use stripe motifs on sports and leisure garments, other competitors may be disadvantaged for a possibly unlimited period of time.

This outcome could not have been the intent of the legislators who developed specific forms of protection for these signs, such as design protection or copyright protection, which expire within a limited period of time. ${ }^{100}$ Trademark proprietors should be encouraged to invest in the quality and attractiveness of the goods or services and not be rewarded with competitive advantages from the sign as such. ${ }^{101}$

\footnotetext{
99 The CJEU has actually already made normative corrections with regard to the public interest under the umbrella of consumer perception. Trademarks with a low degree of distinctiveness or market recognition often receive a strict scope of protection. Since consumers are more easily confused when trademarks are not so well known, this can also be seen as a normative correction against a too broad scope of protection. It would be against the trademark policy to grant more protection to trademark owners who have made fewer investments in market recognition or have chosen a common sign as a trademark. At the same time, by granting a strict scope of protection, the public interest in keeping descriptive signs freely available to third parties on the market can be safeguarded. See Max Planck Institute (2011), p. 58; Ströbele (1991), p. 827.

100 Unlike the classic trademark regimes, patent, industrial, and copyright law protect creative or innovative achievements as such for a limited period of time and later enrich the public domain after this period of time. In contrast, the trademark owner can keep the profits of the success of his marketing campaigns for himself. See Kur and Senftleben (2017), p. 20; Dogan and Lemley (2005), pp. 493, 505; Calboli (2018), pp. 292-293.

101 Kur and Senftleben (2017), pp. 4, 329. See Senftleben et al. (2015), pp. 337, 341.
} 
Exclusive rights to appealing design items may also hinder innovation and stimulate standardisation. ${ }^{102}$ Competitors could be alarmed by Adidas' enforcement strategy and avoid using stripes on sports and leisure clothes at all. As the cases illustrate, the competitors were big players - C\&A, Marca Mode, H\&M, and Nike that are well known among consumers. Moreover, the number of cease-and-desist letters that Adidas sent confidentially is unclear, so we do not know what in fact the impact of Adidas' enforcement strategy has been. ${ }^{103}$

As long as non-distinctive signs can acquire distinctiveness through use in trade, trademark owners will invest in appealing signs that give them a competitive advantage. An investment-based approach would further facilitate this process. Moreover, if national courts do not proactively refer to the need to keep signs freely available in their infringement assessment, the trademark system may finally develop into a self-serving mechanism for the industry. In this marketplace, newcomers have less chance.

As the case analysis surrounding the three-stripe motif illustrates, since Adidas/ Marca several courts seem to have followed this investment-based direction. Having said this, case law analysis for this article was restricted to three-stripe motifs. However, the same problem is conceivable with regard to other signs. Exclusive trademark rights on descriptive, cultural and non-traditional signs may also generate obstacles to competition, since these signs also give trademark proprietors a competitive advantage from the sign as such. ${ }^{104}$

The confusion analysis must therefore be recalibrated. In order to provide enough room for the concerns of trademark owners and competitors (and ultimately also consumers), it is essential to apply normative corrections not only in favour of trademark owners but also in favour of competitors. The Adidas/Marca case must be revisited and the need to keep free must be recognised as an additional factor in the confusion analysis.

Open Access This article is licensed under a Creative Commons Attribution 4.0 International License, which permits use, sharing, adaptation, distribution and reproduction in any medium or format, as long as you give appropriate credit to the original author(s) and the source, provide a link to the Creative Commons licence, and indicate if changes were made. The images or other third party material in this article are included in the article's Creative Commons licence, unless indicated otherwise in a credit line to the material. If material is not included in the article's Creative Commons licence and your intended use is not permitted by statutory regulation or exceeds the permitted use, you will need to obtain permission directly from the copyright holder. To view a copy of this licence, visit http://creativecommons.org/licenses/by/4.0/.

\section{References}

Albrecht F (1999) Sprachwissenschaftliche Erkenntnisse im markenrechtlichen Registerverfahren. Dissertation, Münster (Westf.) University

Bloch PH (1995) Seeking the ideal form: product design and consumer response. J Mark 59(3):16-29

Boes U, Deutsch V (1996) Die "Bekanntheit" nach dem neuen Markenrecht und ihre Ermittlung durch Meinungsumfragen. GRUR 3:168-173

\footnotetext{
102 Calboli (2018).

103 See also Calboli (2018), p. 293; Gibson (2007), pp. 907-908, 912, 916.

104 See Senftleben (2018), p. 309; Calboli (2018), p. 287; Ramsey (2003); Cancellation Division, judgment of 22 May 2019, No. 14145 C, Van Haren Schoenen/Christian Louboutin.
} 
Bone RG (2006) Hunting goodwill: a history of the concept of goodwill in trademark law. Boston Univ Law Rev 86:547-622

Burrell R, Gangjee D (2010) Trade marks and freedom of expression: a call for caution. IIC 41:544

Calboli I (2018) Hands off "my" colors, patterns, and shapes! How non-traditional trademarks promote standardization and may negatively impact creativity and innovation. In: Calboli I, Senftleben MRF (eds) The protection of non-traditional trademarks. Critical perspectives. Oxford University Press, Oxford

Carter SL (1990) The trouble with trademark. Yale Law J 99:762

Celsi RL, Olson JC (1988) The role of involvement in attention and comprehension processes. J Consum Res 15:210-224

Cohen Jehoram T, van Nispen CJJC, Huydecoper JLRA (2010) European trademark law. Community trademark law and harmonized national trademark law. Kluwer International, Alphen aan den Rijn

Creusen MEH, Schoormans JPL (2005) The different roles of product appearance in consumer choice. J Prod Innov Manag 22:63

David L, Frick MR (2017) Basler Kommentar. Markenschutzgesetz. Wappenschutzgesetz. Helbing Lichtenhahn Verlag, Basel

Desai D (2018) Should trademark law protect non-traditional trademarks? A look at how marketing practices try to capture essences. In: Calboli I, Senftleben MRF (eds) The protection of nontraditional trademarks. Critical perspectives. Oxford University Press, Oxford

Dinwoodie GB, Gangjee DS (2016) The image of the consumer in European trade mark law. In: Leczykiewicz D, Weatherill S (eds) The image(s) of the consumer in EU law. Hart Publishing, Oxford

Dogan SL, Lemley MA (2004) Trademarks and consumer search costs on the internet. Houst Law Rev 41(3):777-838

Dogan SL, Lemley MA (2005) The merchandising right: fragile theory or fait accompli. Emory Law J 54(1):461-506

Economides NS (1988) The economics of trademarks. Trademark Rep 78:523-539

Fhima I, Denvir C (2015) An empirical analysis of the likelihood of confusion factors in European trade mark law. IIC 46:310-339

Foxman ER, Muehling DD, Berger PW (1990) An investigation of factors contributing to consumer brand confusion. J Consum Aff 24(1):170-189

Gangjee DS (2013) Property in brands. LSE Law, Society and Economy working papers 8

Gentry JW, Putrevu S, Shultz CJ (2006) The effects of counterfeiting on consumer search. J Consum Behav 5(3):245-256

Gibson J (2007) Risk aversion and rights accretion in intellectual property law. Yale Law J 116(5):882-951

Griffiths A (2008) A law-and-economics perspective on trade marks. In: Bently L, Davis J, Ginsburg J (eds) Trade marks and brands, an interdisciplinary critique. CUP, Cambridge

Han YJ, Nunes JC, Drèze X (2010) Signaling status with luxury goods: the role of brand prominence. J Mark 74(4):15-30

Hughes J (2015) Cognitive and aesthetic functionality in trademark law. Cardozo Law Rev 36(4):1227-1286

Jacoby J (2001) The psychological foundations of trademark law: secondary meaning, genericism, fame, confusion and dilution. Trademark Rep 91:1013-1071

Kabel JJC (2005) Rechter en publieksopvattingen: feit, fictie of ervaring? Over de beoordeling door de rechter van commerciële communicatie. Otto Cramwinkel Uitgever, Amsterdam

Kur A (2018) Yellow dictionaries, red banking services, some candies, and a sitting bunny. Protection of color and shape marks from a German and European perspective. In: Calboli I, Senftleben MRF (eds) The protection of non-traditional trademarks. Critical perspectives. Oxford University Press, Oxford

Kur A, Senftleben MRF (2017) European trade mark law. A commentary. Oxford University Press, Oxford

Landes WM, Posner LA (2003) The economic structure of intellectual property law. Harvard University Press, Cambridge

Lee AY (2002) Effects of implicit memory on memory-based versus stimulus-based brand choice. J Mark Res 39:440-454

Lee TR, DeRosia ED, Christensen GL (2008) Sophistication, bridging the gap, and the likelihood of confusion: an empirical and theoretical analysis. Trademark Rep 98:913

Max Planck Institute for Intellectual Property and Competition Law (2011) Study on the overall functioning of the European trade mark system, Munich

McGeveran W (2008) Four free speech goals for trademark law. Fordham Intellect Prop Media Entertain Law J 18:1205 
McKenna MP (2007) The normative foundations of trademark law. Notre Dame Law Rev 82(5):1899

Nasser M (2009) Trade marks and freedom of expression. IIC 40:188

Oneto S, Sundie JM (1999) Perceptions of counterfeit consumers. Econ Psychol 20(2):147-182

Phillips J (2003) Trade mark law. A practical anatomy. Oxford University Press, New York

Phillips J (2005) Trade mark law and the need to keep free. Intellectual property monopolies have their limits. IIC 36:389-401

Ramsey LP (2003) Descriptive trademarks and the first amendment. Tenn Law Rev 70:1095

Ramsey L, Schovsbo J (2013) Mechanisms for limiting trade mark rights to further competition and free speech. IIC 44(6):671-700

Raßmann C (1997) Verwechslungsgefahr und Schutzumfang im neuen Markenrecht - ein völliger Neubeginn? GRUR 8/9:580-591

Risthaus S (2007) Erfahrungssätze im Kennzeichenrecht. Note 52. Carl Heymanns Verlag GmbH, Cologne/Munich

Sakulin W (2011) Trademark protection and freedom of expression: an inquiry into the conflict between trademark rights and freedom of expression under European law. Kluwer Law International, Alphen aan den Rijn

Schwartz B (2004) The paradox of choice. Why more is less. HarperCollins, New York

Seibt K (2002) Das europäische Verbraucherleitbild - ein Abschied von der "Verwechslungsgefahr als Rechtsfrage"? GRUR 6:465-472

Senftleben MRF (2013) Adapting EU trade mark law to new technologies - back to basics? In: Geiger C (ed) Constructing European intellectual property: achievements and new perspectives. Edward Elgar Publishing, Cheltenham, pp 137-176

Senftleben MRF (2015) Free signs and free use: how to offer room for freedom of expression within the trademark system. In: Geiger C (ed) Research handbook on human rights and intellectual property. Edward Elgar Publishing, Cheltenham, pp 354-376

Senftleben MRF (2018) A clash of culture and commerce. Non-traditional marks and the impediment of cyclic cultural innovation. In: Calboli I, Senftleben M (eds) The protection of non-traditional trademarks. Critical perspectives. Oxford University Press, Oxford

Senftleben MRF, Bentley L, Dinwoodie G, Geiger C, Griffiths J et al (2015) The recommendation on measures to safeguard freedom of expression and undistorted competition: guiding principles for the further development of EU trade mark law. EIPR 37:337-343

Simon Fhima I (2013) Trade marks and free speech. IIC 44:293-321

Solomon M, Bamossy G, Askegaard S, Hogg MK (2008) Consumentengedrag. Pearson Prentice Hall, Amsterdam

Strasser M (2000) The rational basis of trademark protection revisited: putting the dilution doctrine into context. Fordham Intellect Prop Media Entertain Law J 10:379-382

Ströbele P (1991) Verwechslungsgefahr und Schutzumfang. In: Beier F-K et al (eds) Festschrift zum hundertjährigen Bestehen der Deutschen Vereinigung für gewerblichen Rechtsschutz und Urheberrecht, vol 2. VCH, Weinheim

Szmigin I, Piacentini M (2015) Consumer behaviour. Oxford University Press, Oxford

van de Kamp GJ (1999) Is het drie-strepen-merk te bekend? IER 3:101-104

van Horen F (2010) Breaking the mould on copycats: what makes product imitation strategies successful? CentER, Tilburg

van Horen F, Stapel DA, Pieters R (2006-2007) Over het belang van vormen in de waarneming van merken. BMM Bull 4(32):166-170

Veryzer RW Jr, Hutchinson JW (1998) The influence of unity and prototypicality on aesthetic responses to new product designs. J Consum Res 24(4):374-394

Vierheilig W (1982) "Ernsthafte" Verwechslungsgefahr? Überlegungen zu europäischen Reformbestrebungen im Markenrecht. GRUR Int 8/9:506-511

Weatherall K (2017) The consumer as the empirical measure of trade mark law. MLR 80(1):57-87

Wilf S (1999) Who authors trademarks? Cardozo Arts Entertain 17:1-46

Zimmerli A (1975) Der markenrechtlich erforderliche Zeichen- und Warenabstand insbesondere zur sogenannten berühmten Marke. Dissertation, Zürich

Publisher's Note Springer Nature remains neutral with regard to jurisdictional claims in published maps and institutional affiliations. 